\title{
Valuing Aboriginal cultural activity: Beyond markets
}

\author{
Kaely Woods
}

\section{Introduction}

It was an honour to speak at the conference that celebrated the contribution of Jon Altman, the founding Director of the Centre for Aboriginal Economic Policy Research (CAEPR), and to hear others reflect on his work. My lifelong interest and involvement in Indigenous issues, particularly sustainable economic development on terms that meet the needs of Aboriginal and other Australians, has motivated me to undertake a $\mathrm{PhD}$ somewhat later in life.

While Altman was establishing his research career, I was at The Australian National University (ANU) studying undergraduate economics part-time, juggling study with full-time work. The welfare and public economics that stirred my interest was grounded in utility theory, premised on individualism and material objectives. This left me wondering how this framework could accommodate non-monetary utility including Aboriginal cultural values.

After completing an economics degree my career turned to challenging, sometimes rewarding, social and economic policy in the Australian Government departments of Finance, Prime Minister and Cabinet, and Health, and with Indigenous Business Australia. 
In central agency policy roles from the early 1990s, I engaged with Altman and CAEPR across a range of issues, including reviews of the Community Development Employment Projects (CDEP) scheme and related economic development programs. Altman actively sought to engage with policymakers and bureaucrats to achieve two ends: to influence policymakers through imparting knowledge and contextual understanding; and to better inform his own understanding of emerging policy issues and positions.

Here I reflect on aspects of Altman's work that have been, and continue to be, of particular relevance and interest to me. I outline what led to my doctoral research and how this research will extend Altman's project of quantifying the value of Indigenous cultural activity.

\section{Professor Altman's contribution}

I am struck by the extraordinary efforts Altman made to observe, document and analyse economic activity in Arnhem Land, particularly his visits to Mumeka outstation where he embedded himself in the community for two years in order to undertake his doctoral research, and regularly visited in following years.

Altman's early work on hunter-gatherer economies in northern Australia was positioned in a production-focused framework. Reflecting his initial training as an economist, Altman conducted quantitative assessments of production as a participant observer over extended periods. Through these studies he was able to measure and analyse the dietary and market-equivalent values of production; the time and effort exerted in bush food gathering, fishing, and hunting activities; and the seasonality of these activities (Altman 1983, 1984, $1987,2009)$. This research built on the foundation of post-World War II studies of the nutritional value of customary hunting and gathering practices in Arnhem Land (Specht et al. 2000) and paralleled work being done elsewhere in Arnhem Land (Meehan 1982).

Altman's observation and analysis of hunting and gathering in Kuninjku country over extended periods clearly demonstrated the substantial calorific and market-equivalent values of the goods produced or caught (Altman 1983, 1984). The extended immersion and continuing connection that Altman built with the people provided him 
with a greater depth of understanding than previous shorter studies in Arnhem Land. It arguably also ensured less distortion, given that aspects of experimentation in the earlier studies have been shown to impact directly on production and consumption choices (Bird-David et al. 1992).

As an active participant in hunting activity, Altman's observations were not limited to the economic efficiency of cooperative efforts. He also recognised the cultural and social aspects of the production activity. The participatory nature of Altman's research led him to note the significance of other aspects of the customary economy, including distributive arrangements, particularly for large game; trade between groups; tool production; and the production of ritual or religious items. The asymmetry of distribution of game and concepts around demand sharing, which are important aspects of the economic framework operating in these societies, were further explored by Altman, including in work with Peterson (Altman 2009, 2011; Altman \& Peterson 1988).

Recently, Altman (2009) reflected on a 1980 fire drive for hunting macropods in which he participated, considering a number of different aspects of the hunting activity in the hybrid economy model. He identified many spin-off benefits of this activity, including an increased sense of well-being resulting from the demonstration of Kuninjku social norms (including demonstration of older men's authority, sharing and consumption practices, and increased camaraderie); the education of young initiates in both cultural and ecological skills; and ecological management. In economic terms, these activities built social and human capital as they equipped individuals and the society with the skills for ongoing survival and created utility beyond the net calorific benefit of the catch. The apparent value of these activities is more than a market value equivalent to the cost of obtaining a comparable food product from a shop or another provider. Distribution mechanisms for larger game, which Altman noted to be asymmetrical towards more senior hunters in acknowledgement of their standing, could be typified as a return on their social or cultural capital.

Altman's research into Aboriginal involvement in tourism (Altman 1988, 1989b; Altman \& Finlayson 1992) and the Aboriginal arts sector (Altman 1989a) also broke new ground by demonstrating the limits 
of the market and intersections with the customary and government sectors (see also Altman 2001, 2003, 2005). Altman's hybrid economy model is essentially a descriptive tool that sets out to highlight the role of the customary, non-market economy for Aboriginal people in remote areas. In particular, Altman refers to the flexibility hybridity affords in increasing production possibilities in ways that accommodate social and cultural practice, thereby improving well-being above the level that could be achieved by any single sector. Altman has calculated market-equivalent values of productive activity in order to highlight the value of the customary, non-monetary economy.

Activity that builds social and cultural capital is recognised in much of Altman's work but is not given a market-equivalent value. Additional benefits and value are recognised in participation in social hunting, gathering and art creation events, including the way these enable the building and passing on of cultural skills and enhance the standing and recognition of elders (Altman 1983, 2001, 2009). Altman has also recognised the value from activities in the customary economy in quality of life (Altman 1980), building cultural and ecological knowledge or intellectual property (Altman 1983) and biodiversity and ecological management (Altman 2001). These examples demonstrate the role of non-monetised, culturally based activities in building cultural, social and human capital.

Altman recognised the importance of data and greatly strengthened the evidence base for policy development. Altman identified the opportunity for a national survey of Aboriginal and Torres Strait Islander people following a recommendation from the Royal Commission into Aboriginal Deaths in Custody. He convened a workshop of academics and select officials to discuss options and implications of such a survey (Altman 1992). This resulted in a national socioeconomic survey of Australia's Indigenous people, which has continued to develop with ongoing input from Altman and other academics. Sections of the survey reflect Altman's influence in consideration of productive cultural activities such as fishing, hunting, gathering, art production, and performance. Resulting quantitative studies of the relationship between cultural activity and employment using data from the 2002 and 2008 National Aboriginal and Torres Strait Islander Social Surveys are inconsistent (Hunter \& 
Gray 2001, Dockery 2010, Stephens 2010, Dockery 2011). This points to the challenges of interpretation of cultural attachment which may reflect localised sociocultural influences.

\section{Culture and economic development in policy}

Aboriginal perspectives on the relationship between culture and economics have not influenced policy development. Indeed, they have rarely been part of the framework used by policymakers working on Indigenous issues. Aboriginal voices were heard more strongly during the Aboriginal and Torres Strait Islander Commission (ATSIC) years, with the development of strategies and increased funding for programs aimed at the survival and revival of languages and supporting Indigenous art and tourism. In central government policy, programs and approaches that promoted the continuity of cultural practice were never given the same priority as land rights, health, housing, education, and economic development. However, across the country, Aboriginal people have demonstrated continuity in cultural activity and connection to country through native title processes and through land management and employment programs such as CDEP.

CDEP was so central to Indigenous policy for three decades that no consideration of Indigenous employment or economic activity is complete without it. I witnessed CDEP activities in several remote communities that were grounded in social and cultural norms, supporting cultural activity and maintenance. Programs such as women's centres, caring for older people, sharing stories, and arts and crafts development are examples. These activities were consistent with the intent of the Aboriginal Employment Development Policy (AEDP) which was to create appropriate jobs for Aboriginal people in the places they lived while recognising that there were limited market opportunities in remote areas. The AEDP specifically supported 'traditional Aboriginal economic activities as a legitimate form of employment' (Australian Government 1987).

Two common success factors for CDEP were, in my experience, active community engagement in planning and development and implementation that reflected the social and cultural settings of 
individual communities. The prerequisite of a community plan for entry into CDEP encouraged the strengthening of community governance. However, during the period of rapid growth of CDEP in the late 1980s and early 1990s, many community plans were developed by external consultants with little sense of community ownership, resulting in a reduced sense of ground up community development. As a result, some CDEP activities became programmatic work-for-welfare, rather than avenues for community development and employment. As policy debate shifted from self-determination towards the 'real economy' and 'real jobs', CDEP was increasingly viewed as welfare or 'sit down money'. CDEP was sometimes seen as an effective veil over underemployment and unemployment, without due recognition as an effective avenue for community-driven and controlled development.

The 2007 Northern Territory Emergency Response, or Intervention as it became known, confirmed Indigenous policy development as centralised and top down, without broad-based involvement of Aboriginal people. The evolution of economic development policy from the AEDP in an era of self-determination through mutual obligation, the Intervention, and the current promotion and consultation on the Forrest Review (Forrest 2014) has had little consideration of cultural activity, except where it is central, as in art and tourism.

Government documents frequently acknowledge the value of culture to Aboriginal people and society in general, but not in economic terms beyond market value (Macklin et al. 2010). This market value is not necessarily the same as the value to Aboriginal people. Research into well-being and health points to the contribution of culture in providing Aboriginal people with a sense of identity and purpose (McDermott et al. 1998, Eckersley et al. 2001, Dockery 2011).

Cultural policy, which is generally the domain of the federal government, is framed in the 2013 statement Creative Australia with a declared aim to 'ensure that the cultural sector-incorporating all aspects of arts, cultural heritage and the creative industries - has the skills, resources, and resilience to play an active role in Australia's future' (Australian Government 2013). Aboriginal and Torres Strait Islander cultures are prominent in Creative Australia, with the first of five goals being to 'Recognise, respect and celebrate the centrality of Aboriginal and Torres Strait Islander cultures to the uniqueness of 
Australia's identity'. However, there are limited specific actions and recommendations dealing with Indigenous culture. The major focus of the policy relevant to Aboriginal and Torres Strait Islanders, beyond maintaining existing programs, is the preservation of languages and the updating of the National Indigenous Languages Policy. Perusal of the Register of Cultural Organisations (ROCO) ${ }^{1}$ suggests only 30 (1.9 per cent) of the 1,573 organisations recognised and supported by the Australian Government are identifiable as Aboriginal-owned or -controlled. A large proportion of these are performance-based organisations operating in the mainstream market. It seems that there has not been substantive financial support and recognition of culture as determined by Aboriginal people themselves since the ATSIC Cultural Industry Policy of 1997.

\section{Moving beyond market value}

While Altman and others have documented the value of production in the customary economy by considering market price equivalents, I seek to go beyond this by quantifying the value of products and processes that are not commodified.

The question of what is the complete value of cultural activity has not been fully answered by research to date. How can we value the process of group hunting and gathering beyond the calorific and market price equivalent of the product? Can ceremony be valued only according to the tourist dollars it may generate? Does the market value of Aboriginal art reflect its value to artists or does the process of production bring other benefits? By quantifying value beyond markets, is it possible to influence policy consideration of employment and cultural activity?

To answer these questions, it is worth considering developments in environmental economics over the past 30 years. Valuation of environmental amenities, where no explicit market exists, has been a central area of research and development. Partial equilibrium models

1 Register of Cultural Organisations (ROCO) organisations and funds as of 11 September 2013, accessed most recently on 3 November 2014 at arts.gov.au/sites/default/files/collections/registerof-cultural-organisations-roco.pdf. 
from neoclassical welfare economics have been used to calculate shadow prices as estimates of the social prices of public goods or social costs of environmental damage or pollution (Parks \& Gowdy 2013).

The recognition of non-market values has also been achieved in cultural economics, led by Throsby. Research in this field has predominantly focused on the value of cultural goods consumed or cultural heritage assets as public goods using similar methods to those used in environmental economics (Throsby \& Withers 1985; Throsby 1999, 2003; Snowball 2008). Throsby (2006) has also examined the creativity involved in the artistic productive process and its value in terms of innovation and contribution to the artist's human capital. Less attention has been directed to cultural activity as a process of producing cultural goods and services, particularly in Indigenous cultural contexts.

What has been shown in both environmental and cultural economics is that market values are incomplete measures of the value of goods. The demonstration of broader values can justify government support for activities that preserve, enhance and support environmental and cultural activities.

Indigenous cultural tourism and arts are predominantly discretionary goods. Market demand is limited and can fluctuate widely with currency movements and international events (Acker et al. 2013, Ruhanen et al. 2013). Despite this fragility, cultural tourism continues to attract Aboriginal people as a way of earning an income while remaining connected to country and kin. The perceived benefits of these hybrid economic activities extend beyond income generation to the continuity of cultural practices and management of country.

Building and sustaining cultural capital requires ongoing effort and investment. For Aboriginal people, cultural practices such as speaking languages, practicing rituals, and teaching the young are essential to ongoing, living culture and associated identity. This is a much broader understanding of the importance of culture compared to a narrow economic production framework that only counts the market value of food production, artefact sales or cultural tours.

The limitations of market values are also evident in governmentfunded natural resource management programs such as Caring for our Country. The public good nature of the ecological management, border 
protection and biosecurity functions undertaken mean that they are unlikely to underpin sustainable private businesses in the commercial world. They are dependent on government or philanthropic funding for survival. While cultural tourism and art markets are critical elements of economic development in northern Australia, fragility limits their sustainability. Despite this, Aboriginal people participating in these activities frequently report high levels of satisfaction with work of this nature. Using cultural knowledge in the market meets financial needs while also enabling continuing connection to culture and country. This reflects the flexibility and range of production possibilities in the hybrid economy.

For Aboriginal people the choice is sometimes stark: development or culture. In the Kimberley, where I am planning to do fieldwork, Aboriginal people have articulated a desire for economic development and jobs, while also stressing the importance of maintaining culture, expressed through language, traditions and ongoing relationships with country. People often move for work and communities often schedule major cultural business at times that minimise disruption to education and work. These tensions and trade-offs can be used to inform the question of the value of cultural activity.

\section{My research}

My research question is: What is the association between Aboriginal cultural activity and labour supply in remote Australia? I intend to test the tensions and trade-offs between paid employment and cultural activity, using choice modelling to reveal the (non-market) value of cultural activity relative to paid employment. My consideration of cultural activity includes customary production such as hunting, fishing, and gathering; the creation of functional utensils and goods; participation in ceremony and ritual; and associated social interaction.

While my research interests are much broader than employment, a useful lens is to measure the non-market value of cultural activity by testing the trade-offs between cultural activity and paid employment. We know that there is significant disparity in employment levels between Indigenous and other Australians, and there has been considerable research into the education and training differentials that contribute to the labour supply side of this inequity. There have been 
two notable programs in recent years focusing on the demand side with corporate entities setting targets for Indigenous employment: the Australian Employment Covenant (now Generation One); and Reconciliation Action Plans. Both appear to have fallen short of employment targets. The lack of transparency in the Australian Employment Covenant makes assessment difficult (Jordan 2010, Australian National Audit Office 2013, Reconciliation Australia 2013).

There is an identified gap in quantitative research about the relationship between cultural practice and labour supply (Gray et al. 2012). Anthropological studies have variously identified tensions between paid work and maintenance of cultural practices and family obligations (Musharbash 2001, Austin-Broos 2006, McRae-Williams \& Gerritsen 2010, McRae-Williams 2011). Others have pointed to employment income supporting households and facilitating engagement in cultural activity through vehicle ownership and other financial capacity (Sercombe 2008, Scambary 2013). Official measures of employment do not include cultural and social production. Better understanding of the influence of cultural practice on Aboriginal choices to engage with employment is needed to ensure appropriate and effective policies and programs.

My initial qualitative phase of research will confirm the appropriate attributes and levels for the choice modelling. My research will contribute to understanding the association of cultural activity and labour supply in a number of ways:

- Develop an empirical means to compare cultural practice and paid employment that will provide new insights into the relationship between cultural practice and maintenance and the labour supply in remote areas.

- Develop methods to identify and quantify the value of cultural practices, which can in turn indicate employment conditions that maximise the recruitment and retention of Aboriginal employees on mutually acceptable terms with employers.

- Provide explicit valuation of cultural practice that could support a re-examination of national employment policies and targets, perhaps through a classification of remoteness. 
The essence of my project is the recognition of the value of culture and how to ensure Aboriginal viewpoints and choices are integrated into policy. While the idea of capturing the non-market value of cultural activity may seem theoretical, its relevance to behavioural influences for Aboriginal people is stark in policy debates about Aboriginal employment, health, education, and training. Understanding the motivations and values in activities undertaken within and outside the workplace is at the heart of effective employment policies and practices. Understanding why people make the choices they do in employment, training, diet, and other lifestyle factors is the key to successful policy interventions. While economics today is often about Big Data, at its core are still questions about human behaviours and what drives them.

The valuation of cultural activity beyond markets does not equate to commoditisation of culture. Nor is it the solution to entrenched poverty and disadvantage that exists in communities with limited commercial or state-sponsored economies. As I see it, the role of valuation is the explicit recognition of the relative importance of cultural activity as a key to cultural maintenance when considering economic development opportunities and options.

\section{Conclusion}

To say that Altman has influenced my work and research is an understatement. His engagement with senior officials was notable when I worked in central government agencies. The hybrid economy model prompted explicit recognition of Aboriginal economies beyond the market and state sectors. Altman's efforts in quantifying particular aspects of the hybrid economy were relevant in considering arts and tourism opportunities. Going beyond a time study and product assessment approach to valuing Aboriginal cultural activity and its relationship with market employment is breaking new ground. I look forward to the robust engagements with Altman and others that may ensue. 


\section{Acknowledgements}

I would like to thank Jon Altman, Katherine Curchin and Matthew Gray who commented on earlier drafts of this paper.

\section{References}

Acker T, Stefanoff L \& Woodhead A (2013). Aboriginal and Torres Strait Islander art economies project: literature review, CRC-REP Working Paper CW010, Ninti One Limited, Alice Springs.

Altman JC (1980). The Aboriginal economy. In Jones R (ed.) Northern Australia: options and implications, Research School of Pacific Studies, The Australian National University, Canberra.

Altman JC (1983). Eastern Gunwinggu fish trapping at Gunbatgarri. The Beagle, Occasional Papers of the Northern Territory Museum $1: 59-71$.

Altman JC (1984). The dietary utilisation of flora and fauna by contemporary hunter-gatherers at Momega Outstation, northcentral Arnhem Land. Australian Aboriginal Studies 1:35-46.

Altman JC (1987). Hunter-gatherers today: an Aboriginal economy in north Australia, Australian Institute of Aboriginal Studies, Canberra.

Altman JC (1988). Aborigines, tourism, and development: the Northern Territory experience, North Australia Research Unit Monograph, The Australian National University, Darwin.

Altman JC (1989a). The Aboriginal arts and crafts industry: report of the Review Committee, July 1989, Australian Government Publishing Service, Canberra.

Altman JC (1989b). Tourism dilemmas for Aboriginal Australians. Annals of Tourism Research 16:456-76.

Altman JC (ed.) (1992). A national survey of Indigenous Australians: options and implications, CAEPR Research Monograph No. 3, Centre for Aboriginal Economic Policy Research, The Australian National University, Canberra. 
Altman JC (2001). Sustainable development options on Aboriginal land: the hybrid economy in the twenty-first century, Discussion Paper 226, Centre for Aboriginal Economic Policy Research, The Australian National University, Canberra.

Altman JC (2003). Economic development and participation for remote Indigenous communities: best practice, evident barriers, and innovative solutions in the hybrid economy, presentation to the Ministerial Council for Aboriginal and Torres Strait Islander Affairs, Sydney, 28 November.

Altman JC (2005). Development options on Aboriginal land: sustainable Indigenous hybrid economies in the twenty-first century. In Taylor L, Ward GK, Davis R, Henderson G \& Wallis L (eds), The power of knowledge, the resonance of tradition, Aboriginal Studies Press, Canberra.

Altman JC (2009). Manwurrk (fire drive) at Namilewohwo: a landmanagement, hunting and ceremonial event in western Arnhem Land. In Russell-Smith J, Whitehead, P \& Cooke P (eds), Culture, ecology and economy of fire management in north Australian savannas: rekindling the Wurrk tradition, CSIRO Publishing, Collingwood.

Altman JC (2011). A genealogy of 'demand sharing': from pure anthropology to public policy. In Musharbash Y \& Barber M (eds), Ethnography and the production of anthropological knowledge: essays in honour of Nicolas Peterson, ANU E Press, Canberra.

Altman JC \& Finlayson J (1992). Aborigines, tourism and sustainable development, Discussion Paper 26, Centre for Aboriginal Economic Policy Research, The Australian National University, Canberra.

Altman JC \& Peterson N (1988). Rights to game and rights to cash among contemporary Australian hunter-gatherers. In Ingold $\mathrm{T}$, Riches D \& Woodburn J (eds), Hunters and gatherers - property, power and ideology, Berg Publishers, Oxford.

Austin-Broos D (2006). 'Working for' and 'Working' among Western Arrernte in Central Australia. Oceania 76(1):1-15.

Australian Government (1987). Aboriginal Employment Development Policy statement, Australian Government Publishing Service, Canberra. 
Australian Government (2013). Creative Australia. National cultural policy. Commonwealth of Australia, Canberra.

Australian National Audit Office (2013). Indigenous employment: the Australian Government's contribution to the Australian Employment Covenant, ANAO Audit Report No. 55 2012-13, ANAO, Canberra.

Bird-David N, Abramson A, Altman J, Bicchieri M, Burch ES, Ember CR, Endicott KM, Grinker RR, Gudeman S \& Ichikawa M (1992). Beyond 'The Original Affluent Society': a culturalist reformulation [and comments and reply]. Current Anthropology 33(1):25-47.

Dockery AM (2010). Culture and wellbeing: the case of Indigenous Australians. Social Indicators Research, 99:315-32.

Dockery AM (2011). Traditional culture and the wellbeing of Indigenous Australians: an analysis of the 2008 NATSISS, CLMR Discussion Paper Series 2011/01, Centre for Labour Market Research, Curtin University.

Eckersley R, Dixon J \& Douglas RRM (2001). The social origins of health and well-being, Cambridge University Press, Cambridge.

Forrest A (2014). The Forrest review: creating parity, Commonwealth of Australia, Canberra.

Gray M, Hunter B \& Lohoar S (2012). Increasing Indigenous employment rates, Issues Paper No. 3, Closing the Gap Clearinghouse, Australian Institute of Health and Welfare, Canberra \& Australian Institute of Family Studies, Melbourne.

Hunter B \& Gray M (2001). Indigenous labour force status re-visited: factors associated with the discouraged worker phenomenon. Australian Journal of Labour Economics 4(2):111-33.

Jordan K (2010). The Australian Employment Covenant: is it taxpayers' money well spent? Topical Issue 5, Centre for Aboriginal Economic Policy Research, The Australian National University, Canberra.

Macklin J, Evans C, Arbib M \& Australian Government Department of Families, Housing, Community Services \& Indigenous Affairs (2010). Indigenous Economic Development Strategy 2011-2018, Australian Government, Canberra. 
McDermott R, O'Dea K, Rowley K, Knight S \& Burgess P (1998). Beneficial impact of the homelands movement on health outcomes in central Australian Aborigines. Australian and New Zealand Journal of Public Health, 22(6):653-8.

McRae-Williams E (2011). Living with work in a remote Aboriginal community. In Gerritsen R (ed.), North Australian political economy: issues and agendas, Charles Darwin University Press, Darwin.

McRae-Williams E \& Gerritsen R (2010). Mutual incomprehension: the cross cultural domain of work in a remote Australian Aboriginal community. The International Indigenous Policy Journal 1(2):1-27.

Meehan B (1982). Shell bed to shell midden, Australian Institute of Aboriginal Studies, Canberra.

Musharbash Y (2001). Yuendumu CDEP: the Warlpiri work ethic and Kardiya staff turnover. In Morphy F \& Sanders WG (eds) The Indigenous welfare economy and the CDEP scheme, CAEPR Research Monograph No. 20, ANU E Press, Canberra.

Parks S \& Gowdy J (2013). What have economists learned about valuing nature? A review essay. Ecosystem Services 3:el-el0.

Reconciliation Australia (2013). Reconciliation Action Plan impact measurement report 2012, Reconciliation Australia, Canberra.

Ruhanen L, Whitford M \& McLennan C (2013). Demand and supply issues in Indigenous tourism: a gap analysis, final report prepared for Indigenous Business Australia \& Australian Government Department of Resources, Energy and Tourism's Indigenous Tourism Working Group, School of Tourism, University of Queensland \& Griffith University, Brisbane.

Scambary B (2013). My country, mine country: Indigenous people, mining and development contestation in remote Australia, CAEPR Research Monograph No. 33, ANU E Press, Canberra.

Sercombe H (2008). Living in two camps: the strategies Goldfields Aboriginal people use to manage in the customary economy and the mainstream economy at the same time. Australian Aboriginal Studies 2:16-31. 
Snowball JD (2008). Measuring the value of culture: methods and examples in cultural economics, Springer-Verlag, Berlin.

Specht RL, McArthur M \& McCarthy FD (2000). Nutrition studies (1948) of nomadic Aborigines in Arnhem Land, northern Australia. Asia Pacific Journal of Clinical Nutrition, 9(3):215-23.

Stephens BJ (2010). The determinants of labour force status among Indigenous Australians. Australian Journal of Labour Economics 13(3):287-312.

Throsby D (1999). Cultural capital. Journal of Cultural Economics 23:3-12.

Throsby D (2003). Determining the value of cultural goods: how much (or how little) does contingent valuation tell us? Journal of Cultural Economics 27:275-85.

Throsby D (2006). An artistic production function: theory and an application to Australian visual artists. Journal of Cultural Economics 30:1-14.

Throsby D \& Withers G (1985). What price culture? Journal of Cultural Economics 9:1-34. 
This text is taken from Engaging Indigenous Economy: Debating diverse approaches, edited by Will Sanders, published 2016 by ANU Press, The Australian National University, Canberra, Australia. 